\title{
ITERATIVE APPROXIMATIONS FOR MULTIVALUED NONEXPANSIVE MAPPINGS IN REFLEXIVE BANACH SPACES
}

\author{
Yisheng Song AND YeOL Je ChO
}

Abstract. In this paper, we established the strong convergence of Browder type iteration $\left\{x_{t}\right\}$ for the multivalued nonexpansive nonself-mapping $T$ satisfying the weakly inwardness condition in a reflexive and strictly convex Banach space $E$ with a uniformly Gâteaux differentiable norm or in a reflexive Banach space with weakly sequentially continuous duality mapping. Furthermore, we also obtained the strong convergent results for the Halpern type iteration $\left\{x_{n}\right\}$ for multivalued nonexpansive nonself-mapping $T$.

Mathematics subject classification (2000): 47H05, 47H10, 47H17.

Keywords and phrases: Multivalued nonexpansive mapping, strong convergence, reflexive and strictly convex Banach space, weakly sequentially continuous duality mapping, uniformly Gáteaux differentiable norm..

\section{REFERENCES}

[1] G. L. ACEDO AND H. K. XU, Remarks on multivalued nonexpansive mappings, Soochow J. Math. 21 (1995), 107-115.

[2] N. A. ASSAD AND W. A. KIRK, Fixed point theorems for set-valued mappings of contractive type, Pacific J. Math. 43 (1972), 553-562.

[3] D. Downing AND W. A. KIRK, Fixed point theorems for set-valued mappings in metric and Banach spaces, Math. Japon. 22 (1977), 99-112.

[4] E. L. Dozo, Multivalued nonexpansive mappings and Opial's condition, Proc. Amer. Math. Soc. 38 (1973), 286-292.

[5] J. P. GosSEZ AND E. L. DoZO, Some geometric properties related to the fixed point theory for nonexpansive mappings, Pacfic J. Math. 40(1972), 565-573.

[6] S. ITOH AND W. TAKAHASHI, Singlevalued mappings, multivalued mappings and fixed point theorems, J. Math. Anal. Appl. 59 (1977), 514-521.

[7] J. S. JUNG, Strong convergence theorems for multivalued nonexpansive nonself-mappings in Banach spaces, Nonlinear Anal., in press.

[8] W. A. KIRK, Transfinte methods in metric fixed point theorey. Abstract and Appl. Anal. 2003(2003), 311-324.

[9] H. M. Ko, Fixed point theorems for point-to-set mappings and the set of fixed points, Pacific J. Math. 42 (1972), 369-379.

[10] T. C. LIM, A fixed point theorem for multivalued nonexpansive mappings in a uniformly convex Banach space, Bull. Amer. Math. Soc. 80 (1974), 1123-1126.

[11] T. C. LIM, Remarks on some fixed point theorems, Proc. Amer. Math. Soc. 60 (1976), 179-182.

[12] R. E. Megginson, An introduction to Banach space theory, Springer-Verlag, New York, Inc., 1998.

[13] S. B. NADlER, JR., Multi-valued contraction mappings, Pacific J. Math. 30(1969), 475-487.

[14] Z. OPIAL, Weak convergence of the sequence of successive approximations for nonexpansive mappings, Bull. Amer. Math. Soc. 73 (1967), 591-597.

[15] P. PIETRAMALA, Convergence of approximating fixed points sets for multivalued nonexpansive mappings, Comment. Math. Univ. Carolinae 32 (1991), 697-701.

[16] D. R. SAHU, Strong convergence theorems for nonexpansive type and non-self multi-valued mappings, Nonlinear Anal. 37 (1999), 401-407

[17] Y. S. SONG AND R. D. CHEN, Viscosity approximation methods for nonexpansive nonself-mappings, J. Math. Anal. Appl. 321(2006), 316-326. 
[18] Y. S. SONG AND R. D. CHEN, Strong convergence theorems on an iterative method for a family of finite nonexpansive mappings, Appl. Math. Comput. in press.

[19] W. TAKAHASHI AND Y. UEDA, On Reich's strong convergence for resolvents of accretive operators, J. Math. Anal. Appl. 104(1984), 546-553.

[20] W. TAKAHASHI, Nonlinear Functional Analysis - Fixed Point Theory and its Applications, Yokohama Publishers, Inc., Yokohama, 2000 (Japanese).

[21] H. K. XU AND X. M. YIN, Strong convergence theorems for nonexpansive nonself-mappings, Nonlinear Anal. 24 (1995), 223-228.

[22] H. K. XU, Approximating curves of nonexpansive nonself mappings in Banach spaces, C. R. Acad. Sci. Paris, Ser. I. 325 (1997), 179-184.

[23] H. K. XU, An iterative approach to quadratic optimization, J. Optim. Theory Appl. 116(2003), 659-678.

[24] H. K. XU, Viscosity approximation methods for nonexpansive mappings, J. Math. Anal. Appl. 298 (2004), 279-291.

[25] H. K. XU, Multivalued nonexpansive mappings in Banach spaces, Nonlinear Anal. 43 (2001) 693-706.

[26] H. K. XU, Strong convergence of an iterative method for nonexpansive and accretive operators, J. Math. Anal. Appl. 314 (2006) 631-643.

[27] K. YANAGI, On some fixed point theorems for multivalued mappings, Pacific J. Math. 87(1980), 233-240. 